\title{
Pengaruh Faktor Internal dan Faktor Eksternal Terhadap Harga Saham Perusahaan Sektor Pertambangan di ISSI
}

\author{
The influence of internal and external factors towards the stock prices of mining sector \\ companies in ISSI
}

\section{Kirana Arenggaraya}

Program Studi D4 Keuangan Syariah, Politeknik Negeri Bandung

Email: kiranaarenggaraya@gmail.com

\section{Tjetjep Djuwarsa}

Jurusan Akuntansi, Politeknik Negeri Bandung

Email: tjetjepdjuwarsa@yahoo.com

\begin{abstract}
This study was made to analyze the influence of both internal and external factors towards stock prices of mining sector companies listed on Indeks Saham Syariah Indonesia (ISSI). Internal factors that used are Return On Assets (ROA) and Current Ratio (CR), and for the external factors are inflation and Gross Domestic Product (GDP). Stock prices used in this study is stock prices of mining sector companies that consistently listed in ISSI from December 2012 to May 2019. The sample consisted of 17 companies. All of the data were obtained from the official websites of Bursa Efek Indonesia, Bank. Indonesia, and the World Bank. Data Panel Regression Analysis is used in this study, using Eviews 11. This study's results are: partially $\mathrm{RO} A$ bas a positive and significant influence on stock prices, while partially CR, inflation, and GDP has positive and insignificant influences on stock. prices. Simultaneously $\mathrm{ROA}, \mathrm{CR}$, inflation, and GDP have a positive and significant influence on stock prices.
\end{abstract}

Keywords: Return on Assets (ROA), Current Ratio (CR), inflation, Gross Domestic Product (GDP), stock, prices, ISSI.

\section{Pendahuluan}

Bahan tambang yang termasuk dalam sumber daya alam itu tersebar di Indoenesia. Melimpahnya hasil tambang di Indonesia berdampak pada bermunculannya perusahaan pada sektor pertambangan (Nadya dkk., 2020). Badan Pusat Statistik menyebutkan bahwa 50 perusahaan sektor pertambangan sudah terdaftar di Indonesia. Demikian pula Kementrian Lingkungan Hidup yang turut andil dalam pengelolaan alam terkait adanya perusahaan pada sektor pertambangan, dengan mendirikan Program Penilaian Peringkat Kinerja Perusahaan Dalam Pengelolaan Lingkungan (PROPER). Dengan PROPER, dapat menurunkan jumlah eksploitasi alam dan memberikan semangat pada perusahaan sektor pertambangan agar masuk ke dalam peringkat PROPER

Menurut Pew Forum On Religion And Public Life (2009), masyarakat yang menganut Agama Islam di Indonesia ada sebanyak 209.100.000 orang, dimana merupakan 97\% jumlah penduduk. Banyaknya umat Muslim di Indonesia mendorong dilakukannya kegiatan yang sesuai dengan prinsip syariah, termasuk lembaga keuangan (Suhartanto dkk., 2018). Lembaga 
keuangan ini tentu sesuai ajaran Al-Qur'an dan As-Sunnah. Dalam Islam pun ada etika bisnis yang mengacu pada tauhid dan ikhsan (Nurrachmi \& Setiawan, 2020).

Lembaga khusus yang menangani aktivitas lembaga keuangan syariah dan lembaga bisnisnya ialah Dewan Syariah Nasional (DSN). DSN dibentuk guna memantau produkproduk lembaga keuangan syariah agar tidak keluar dari syariat Islam. Ada dua macam lembaga keuangan, yakni lembaga keuangan bank dan lembaga keuangan non-bank.

Pasar modal syariah termasuk dalam lembaga keuangan non-bank dan memiliki produk yaitu surat berharga syariah atau efek syariah. Industri keuangan non-bank menjadi salah satu alternatif dalam melakukan investasi (Setyowati \& Sartika, 2019). Efek syariah yang telah diterbitkan terdiri dari saham syariah, sukuk, dan Unit Penyertaan dari Reksa Dana Syariah.

Berkembangnya pasar modal di Indonesia berimbas dari munculnya Indeks Saham Syariah Indonesia (ISSI) dan Jakarta Islamic Index (JII). ISSI serta JII mengelola jalannya saham syariah yang ada di Indonesia. Menurut Simamora (2016) ISSI pada tahun 2016 menjadi indeks saham yang tumbuh cukup tinggi. Hal ini menjadi daya pikat investor untuk menggeluti saham syariah.

Merujuk dari IDX (2018) jumlah saham syariah di Indonesia meningkat ISSI memiliki 371 perusahaan yang terdaftar, JII hanya 30 perusahaan. Tolak ukur memilih indeks saham yang sesuai yaitu dengan membandingkan ISSI dan JII. Menurut Bapepam-LK, sejak 2011 hingga 2012 ada sebanyak 258 saham di ISSI yang sukses memiliki peningkatan dan pertumbuhan indeks sebanyak 12,72\%. JII hanya mampu 30 saham (Fahmi, Johan Tri Mahardadi, 2011). Dengan begitu ISSI memiliki peningkatan dan pertumbuhan yang lebih baik dibanding JII. Sektor perusahaannya juga bermacam-macam sehingga investor memiliki banyak pilihan.

Liputan 6 menyebutkan bahwa harga saham perusahaan sektor pertambangan menguat $11,45 \%$ pada tahun 2018. Hal ini memperlihatkan harga saham sektor pertambangan menunjukkan performa yang cukup baik. Kinerja keuangan dinilai menjadi salah satu aspek yang berdampak pada harga saham. Beraneka bagian dapat dijadikan nilai untuk kinerja keuangan, salah satunya ialah rasio keuangan. Jenis rasio keuangan ada empat, yakni rasio profitabilitas, rasio likuiditas, rasio solvabilitas, dan rasio aktivitas. Terpilih dua jenis rasio keuangan untuk penelitian ini, yakni rasio profitabilitas dan rasio likuiditas. Rasio profitabilitas yang dipakai yakni Return on Assets (ROA) sedangkan rasio likuiditasnya adalah Current Ratio (CR).

Menurut Sartono (2019) kemampuan perusahaan dalam memperoleh keuntungan dari aset yang dipakai oleh perusahaan tersebut dapat diukur oleh ROA. Setyowati (2018) mengatakan bahwa ROA yang semakin kecil mengindikasikan kurangnya kemampuan perusahaan dalam mengelola aktiva guna meningkatkan pendapatan dan atau menekannya. Menurut Atmaja (2008) rasio keuangan yang dipakai guna mengetahui likuiditas suatu perusahaan merupakan arti dari CR. Tingkat CR yang kecil menandakan bahwa likuiditas perusahaan tersebut rendah, begitupula sebaliknya.

Selain dipengaruhi kinerja keuangan perusahaan yang merupakan bagian dari internal perusahaan, harga saham juga dipengaruhi oleh faktor eksternal. Salah satu faktornya ialah faktor makroekonomi. Terdapat cukup banyak faktor makroeonomi, diantaranya adalah inflasi dan Produk Domestik Bruto (PDB).

Sukirno (2005) menuturkan bahwa inflasi adalah proses peningkatan harga-harga yang berlaku dalam suatu perekonomian. Inflasi tinggi berdampak pada turunnya pendapatan riil masyarakat yang akan mempengaruhi standar hidup masyarakat. Tidak stabilnya inflasi menyulitkan masyarakat untuk memutuskan konsumsinya, demikian juga dengan berinvestasi dan produksi. Akhirnya akan berdampak pada harga saham. Merujuk dari Rakasetya (2013) 
terjadinya inflasi dapat mendesak investor untuk menyimpan dananya dan tidak menanam modal karena beresiko tinggi.

Mankiw (2010) menuturkan bahwa PDB merupakan nilai pasar semua barang dan jasa akhir yang dibuat oleh satu negara dalam periode tertentu. Pertumbuhan ekonomi bersambungan dengan harga saham. Pertumbuhan ekonomi ini menjelaskan peningkatan taraf hidup yang dapat dilihat dengan pendapatan riil. Peningkatan taraf hidup masyarakat dapat berdampak pada harga saham, karena jika masyarakat sejahtera berarti masyarakat telah memenuhi kebutuhannya dan akan menyalurkan kelebihan dananya ke hal lain, salah satunya investasi. Semakin terjamin kesejahteraan masyarakat maka akan berdampak pada harga saham.

Tabel. 1 Data Harga Saham Penutupan, ROA, CR, Inflasi dan PDB pada Perusahaan Sampel

\begin{tabular}{|c|c|c|c|c|c|c|}
\hline Tahun & 2013 & 2014 & 2015 & 2016 & 2017 & 2018 \\
\hline $\begin{array}{l}\text { Harga } \\
\text { Saham }\end{array}$ & $\begin{array}{ll}\text { Rp } & 64\end{array}$ & $\begin{array}{ll}\mathrm{Rp} & 67\end{array}$ & $\begin{array}{ll}\mathrm{Rp} & 56\end{array}$ & $\begin{array}{ll}\mathrm{Rp} & 80\end{array}$ & $\begin{array}{ll}\mathrm{Rp} & 99\end{array}$ & Rp 119 \\
\hline ROA & $0,15 \%$ & $0,28 \%$ & $0,32 \%$ & $3,39 \%$ & $0,67 \%$ & $0,46 \%$ \\
\hline CR & $107,90 \%$ & $108,6 \%$ & $187,81 \%$ & $189,40 \%$ & $189,02 \%$ & $195,25 \%$ \\
\hline Inflasi & $8,38 \%$ & $8,36 \%$ & $3,35 \%$ & $3,02 \%$ & $3,61 \%$ & $3,13 \%$ \\
\hline PDB & Rp 912.524 & Rp 890.815 & Rp 860.854 & Rp 931.877 & Rp 1.015.000 & Rp 1.042.000 \\
\hline
\end{tabular}

Tabel. 1 di atas menyajikan data harga saham penutupan, ROA, CR, inflasi, dan PDB di Indonesia pada salah satu perusahaan sektor pertambangan yang ada di ISSI. Fenomena dapat diketahui pada setiap variabel. ROA pada tahun 2015 meningkat namun harga saham menurun, seharusnya yang terjadi sebaliknya. Fenomena tersebut ada pada tahun 2017 dan 2018.

Fenomena lain terdapat pada CR. Pada tahun 2015 CR meningkat namun harga sahamnya menurun, seharusnya yang terjadi sebaliknya. Begitu pula dengan tahun 2017 di mana CR menurun namun harga saham meningkat. Inflasi juga terdapat fenomena. Tahun 2015 inflasi menurun namun harga saham mengalami penurunan pula, seharusnya yang terjadi sebaliknya. Pada tahun 2017 pun sama, inflasi meningkat namun harga saham ikut meningkat. PDB juga dapat dilihat fenomena. Pada tahun 2014, PDB menurun namun harga saham meningkat seharusnya yang terjadi sebaliknya.

Berdasarkan beberapa pernyataan sebelumnya, diputuskanlah sebuah penelitian berjudul "Pengaruh Faktor Internal dan Faktor Eksternal Terhadap Harga Saham Perusahaan Sektor Pertambangan di ISSI".

\section{Kajian Pustaka}

\subsection{Landasan Teori}

\section{Saham Syariah}

Menurut OJK (2018) dengan konsep saham berarti sebuah efek yang sesuai dengan prinsip syariah. Terdapat persyaratan agar saham-saham termasuk bagian dari saham syariah. perusahaan-perusahaan yang sahamnya masuk dalam kategori saham syariah memiliki perbedaan atau keterbatasan, baik dari sisi pendanaan maupun dari sisi pendapatan (Mai \& Setiawan, 2020)

\section{Harga Saham}

Merujuk dari Hartono (2010) harga saham didefinisikan sebagai harga suatu saham yang terdapat pada pasar bursa yang ditentukan oleh pelaku pasar dan permintaan serta penawaran saham tersebut yang ada di pasar modal. Tingginya harga menyumbangkan keuntungan berupa capital gain dan nilai yang baik, dimana akan membawa akibat baik bagi perusahaan. 


\section{Indeks Saham Syariah Indonesia (ISSI)}

ISSI yang didirikan pada tahun 2011 ini merupakan indeks komposit saham syariah yang ada di Bursa Efek Indonesia (BEI). ISSI menjadi indikator kinerja pasar saham syariah Indonesia.

\section{Rasio Profitabilitas}

Kasmir (2014) menyebutkan bahwa rasio yang dipakai guna mengukur kemampuan perusahaan untuk menghasilkan laba adalah rasio profitabilitas. Tujuannya adalah mengukur tolak ukur perkembangan perusahaan dalam waktu tertentu juga mencari penyebab adanya perubahan pada perusahaan tersebut.

\section{Return on Assets (ROA)}

Merujuk dari Kasmir (2014)) rasio yang memperlihatkan return atas jumlah aktiva yang dipakai perusahaan merupakan arti dari ROA. Tujuannya adalah mengukur potensi perusahaan untuk mendapatkan keuntungan dari total aset perusahaan tersebut (Hijriyani \& Setiawan, 2017). Semakin tinggi ROA menandakan kinerja perusahaan yang semakin baik, akibat dari pengembalian investasi yang semakin besar (Wild, John, K.R. Subramanyam, 2005). Rumus ROA merujuk dari Sartono (2019)

$$
R O A=\frac{\text { Laba Bersih Setelah Pajak }}{\text { Total Aset }}
$$

\section{Rasio Likuiditas}

Munawir (2010) mengatakan bahwa rasio likuiditas ialah rasio yang dipakai guna menganalisis posisi keuangan jangka pendek dan membantu manajemen untuk mengecek efisiensi modal kerja yang dipakai.

\section{Current Ratio (CR)}

Kasmir (2014) menyatakan bahwa CR artinya rasio guna menilai potensi perusahaan dalam mengembalikan kewajiban jangka pendeknya. CR yang tinggi belum tentu menjamin dibayarnya utang perusahaan karena proporsi aktiva lancar yang tidak menguntungkan. Rumusnya adalah;

$$
C R=\frac{\text { Aset Lancar }}{\text { Utang Lancar }}
$$

\section{Makro Ekonomi}

Menurut Dombusch dalam Witjaksono (2010) makro ekonomi adalah ilmu yang fokus pada interaksi tenaga kerja, aset ekonomi dan perputaran barang suatu negara yang berdampak pada peningkatan perdagangan negara tersebut. Samsul (2006) mengatakan bahwa faktor ekonomi makroo dapat mempengaruhi kinerja perusahaan dan harga saham. Faktor makro ekonomi ini muncul dari luar perusahaan dan dapat mempengaruhi peningkatan atau penurunan kinerja perusahaan.

\section{Inflasi}

Merujuk dari Boediono (1999) ) inflasi dapat diartikan sebagai kenaikan harga di pasaran secara kontinyu dan kian melonjak. Menurut Selviarindi (2011) kenaikan harga ini akan berdampak pada konsumsi riil yang akan menjadi rendah. Hal ini dapat pula berdampak pada tingkat pendapatan dan keuntungan perusahaan yang akan semakin menurun yang pada akhirnya berpengaruh pada harga saham yang turun pula. Namun Tripuspitorini \& Setiawan (2020) mengungkapkan bahwa tingkat harga yang dianggap tinggi belum tentu menunjukkan inflasi. Rumus inflasi merujuk dari Natsir (2014): 


$$
\text { Inflasi }=\frac{I H K n-I H K n-1}{I H K n-1} \times 100 \%
$$

\section{Produk Domestik Bruto (PDB)}

Produk Domestik Bruto adalah nilai barang atau jasa dalam satu negara yang dihasilkan oleh faktor-faktor produksi milik warga negara tersebut dan pula negara asing. Mankiw (2010) mengungkapkan bahwa PDB adalah ukuran tunggal terbaik yang memiliki hubungan dengan kesejahteraan masyarakat, karena PDB menilai dua hal di waktu yang sama, yaitu total pendapatan masyarakat dan total pembelanjan negara hasil perekonomian.Rumus PDB merujuk dari Mankiw (2010):

$$
P D B=C+I+G(X-M)
$$

\subsection{Kerangka Pemikiran}

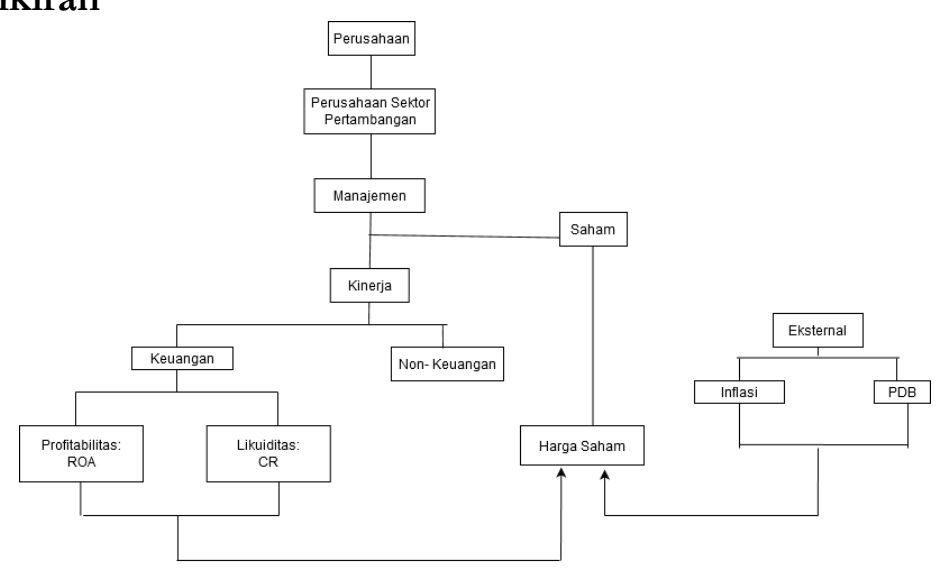

Gambar 1. Kerangka Pemikiran

\subsection{Hipotesis}

\section{Pengaruh Return on Assets (ROA) terhadap Harga Saham}

ROA yang tinggi berbanding lurus dengan kenaikan harga saham. Keuntungan tinggi memikat investor untuk berinvestasi.Penelitian Ananda (2018) menyebutkan ROA berpengaruh positif signifikan terhadap harga saham secara parsial. Maka, hipotesis pertama adalah:

$\mathrm{H}_{1}$ : Diduga ROA secara parsial berpengaruh positif dan signifikan terhadap harga saham.

\section{Pengaruh Current Ratio (CR) terhadap Harga Saham}

CR yang tinggi berdampak pada tingginya harga saham, diakibatkan dari perusahaan yang mampu melunasi kewajiban jangka pendeknya. Penelitian Ananda (2018) menunjukkan CR berpengaruh positif signifikan terhadap harga saham secara parsial. Maka, hipotesis yang kedua adalah:

$\mathrm{H}_{2}$ : Diduga CR secara parsial berpengaruh positif dan signifikan terhadap harga saham.

\section{Pengaruh Inflasi terhadap Harga Saham}

Inflasi tinggi dapat menjatuhkan harga saham, begitu pula sebaliknya. Penelitian Artiani \& Sari (2019) menyebutkan bahwa inflasi berpengaruh negatif signifikan terhadap harga saham secara parsial. Maka, hipotesis yang ketiga adalah:

$\mathrm{H}_{3}$ : Diduga inflasi secara parsial berpengaruh negatif dan signifikan terhadap harga saham.

\section{Pengaruh Produk Domestik Bruto terhadap Harga Saham}

Pertumbuhan ekonomi meningkat sehingga daya beli masyarakatnya pun meningkat dan berdampak pada keuntungan perusahaan yang akan mempengaruhi pula harga saham. 
Penelitian Sholihah (2018) mengatakan PDB berpengaruh signifikan terhadap harga saham secara parsial. Maka, hipotesis yang keempat adalah:

$\mathrm{H}_{4}$ : Diduga PDB secara parsial berpengaruh positif dan signifikan terhadap harga saham.

Pengaruh ROA, CR, inflasi, dan PDB terhadap Harga Saham

Merujuk penelitian Ananda (2018) ROA, CR, TATO, PER dan volume perdagangan berpengaruh signifikan terhadap harga saham secara simultan. Penelitian Sholihah (2018) menyatakan bahwa nilai tukar, inflasi, PDB dan kinerja lingkungan berpengaruh terhadap harga saham secara simultan. Maka, hipotesis yang kelima adalah:

$\mathrm{H}_{5}$ : Diduga ROA, CR, inflasi, dan PDB secara simultan berpengaruh positif dan signifikan terhadap harga saham.

\section{Metode Penelitian}

Menurut Sugiyono (2014) metode penelitian berdefinisi cara guna memiliki data dan memiliki tujuan untuk mendapat hasil yang akurat dari permasalahan pada objek yang diteliti Metode penelitian kuantitatif dengan pendekatan deskriptif adalah metode yang dipakai dalam penelitian ini.

Merujuk dari Sugiyono (2014) populasi berdefinisi wilayah generalisasi yang terdiri dari: objek atau subjek dengan kualitas dan karakteristik yang diterapkan peneliti untuk dipelajari dan ditarik kesimpulannya. Pada penelitian ini, digunakan populasi perusahaan sektor pertambangan yang terdaftar dalam ISSI periode Desember 2012 sampai dengan Mei 2019. Terdapat 27 perusahaan yang menjadi populasi.

Menurut Sugiyono (2014) sampel ialah aspek dari jumlah dan karakteristik yang ada dari populasi. Pada penelitian ini, sampel diambil dengan cara purposive sampling yang merupakan cara penentuan sampel dengan kriteria tertentu, dengan adanya batasan kriteria. Kriteria dalam pengambilan sampel ini yaitu perusahaan yang tetap atau konsisten terdaftar dalam ISSI periode Desember 2012 sampai dengan Mei 2019 dan memiliki data harga saham, ROA, dan CR yang lengkap. Terdapat 17 perusahaan yang memenuhi kriteria, yaitu:

Tabel.2 Sampel Penelitian

\begin{tabular}{|l|l|l|l|l|l|}
\hline No & $\begin{array}{l}\text { Kode } \\
\text { Perusahaan }\end{array}$ & Nama Perusahaan & No & $\begin{array}{l}\text { Kode } \\
\text { Perusahaan }\end{array}$ & Nama Perusahaan \\
\hline 1 & ADRO & PT Adaro Energy Tbk. & 10 & ITMG & $\begin{array}{l}\text { PT Indo Tambangraya } \\
\text { Megah Tbk }\end{array}$ \\
\hline 2 & ARII & P T. Atlas Resources Tbk. & 11 & KKGI & $\begin{array}{l}\text { PT Resource Alam } \\
\text { Indonesia Tbk. }\end{array}$ \\
\hline 3 & ANTM & $\begin{array}{l}\text { P T Aneka Tambang } \\
\text { (Persero) Tbk. }\end{array}$ & 12 & MITI & $\begin{array}{l}\text { PT. Mitra Investindo } \\
\text { Tbk. }\end{array}$ \\
\hline 4 & BSSR & $\begin{array}{l}\text { PT Baramulti } \\
\text { Suksessarana Tbk }\end{array}$ & 13 & MYOH & $\begin{array}{l}\text { PT Samindo Resources } \\
\text { Tbk. }\end{array}$ \\
\hline 5 & CTTH & $\begin{array}{l}\text { PT Citatah Tbk. } \\
6\end{array}$ & 14 & PTBA & $\begin{array}{l}\text { PT Tambang Batubara } \\
\text { Bukit Asam (Persero) } \\
\text { Tbk. }\end{array}$ \\
\hline 7 & ELSA & P T Darma Henwa Tbk. & 15 & SMRU & PT. SMR Utama Tbk. \\
\hline 8 & HRUM & PT. Harum Energy Tbk. & 17 & TOBA & $\begin{array}{l}\text { PT Toba Bara Sejahtra } \\
\text { Tbk. }\end{array}$ \\
\hline 9 & INCO & PT. Vale Indonesia Tbk. & & & TINS \\
\hline
\end{tabular}

Data sekunder dipilih dalam penelitian ini. Menurut Sugiyono (2014) data sekunder ialah data yang didapat dari sumber seperti buku, literatur, dokumen, atau laporan perusahaan. Jenis data yang dipakai dalam penelitian ini adalah data panel yang adalah penggabungan data time 
series dan data cross section. Datanya bersumber dari situs resmi Bursa Efek Indonesia, Bank Indonesia dan World Bank. Model analisis datanya adalah model regresi data panel. Alat bantu analisisnya adalah Eviews 11.

Dalam penelitian ini terdapat beberapa tahapan dalam menganalisa data kuantitatif, diantaranya ialah pemilihan model regresi data panel, uji asumsi klasik, dan uji hipotesis. Pada tahap estimasi model regresi data panel terdapat tiga uji, yakni uji chow, uji hausman, dan uji lagrange multiplier (jika dibutuhkan). Pada tahap uji asumsi klasik terdapat empat uji yakni uji normalitas, uji multikolinearitas, uji heteroskedastisitas, dan uji autokorelasi. Untuk tahap uji hipotesis terdapat dua uji yakni uji t-statistik dan uji Fstatistik.

\section{Hasil dan Pembahasan}

4.1. Pengujian Model Regresi Data Panel dan Hasil Regresi Data Panel

4.1.1. Uji Chow

Di bawah ini ialah hasil Uji Chow menggunakan Eviews 11:

Tabel. 3 Hasil Uji Chow

\begin{tabular}{lrrr} 
Effects Test & Statistic & d.f. & Prob. \\
\hline Cross-section F & 46.012810 & $(16,81)$ & 0.0000 \\
Cross-section Chi-square & 235.766960 & 16 & 0.0000 \\
\hline
\end{tabular}

Dapat diperoleh bahwa nilai Probabilitas Cross-Section F sebesar 0,0000, yakni kurang dari taraf 0,05. Diketahui pula nilai Probabilitas Cross-section Chi-square sebesar 0,0000, yakni kurang dari 0,05. Artinya, model regresi yang terpilih adalah model Fixed Effect.

4.1.2. Uji Hausman

Di bawah ini ialah hasil Uji Hausman menggunakan Eviews 11:

Tabel. 4 Hasil Uji Hausman

\begin{tabular}{lrrr} 
Test Summary & $\begin{array}{c}\text { Chi-Sq. } \\
\text { Statistic }\end{array}$ & Chi-Sq. d.f. & Prob. \\
\hline Cross-section random & 13.496181 & 4 & 0.0091
\end{tabular}

Dapat diketahui bahwa nilai Probabilitas Cross-Section Random sebesar 0,0091, yakni kurang dari taraf 0,05. Artinya, model regresi yang terpilih adalah tetap model Fixed Effect.

4.1.3. Hasil Regresi Data Panel

Berikut hasil regresi data panel dari model Fixed Effect:

Tabel. 5 Hasil Regresi Data Panel 


\begin{tabular}{crlrr} 
Variable & Coefficient & \multicolumn{1}{c}{ Std. Error } & t-Statistic & Prob. \\
& & & & \\
\hline C & 2.386303 & 1.611446 & 1.480846 & 0.1419 \\
ROA & 0.025706 & 0.005214 & 4.930582 & 0.0000 \\
CR & 0.000880 & 0.000452 & 1.946281 & 0.0545 \\
INFLASI & 0.012541 & 0.029334 & 0.427522 & 0.6699 \\
PDB & 0.027418 & 0.330431 & 0.082976 & 0.9340 \\
& & & & \\
\hline & & & & \\
Root MSE & 0.584073 & R-squared & & 0.230227 \\
Mean dependent var & 2.888369 & Adjusted R-squared & 0.198483 \\
S.D. dependent var & 0.668999 & S.E. of regression & 34.79646 \\
Akaike info criterion & 1.860459 & Sum squared resid & -89.88341 \\
Schwarz criterion & 1.989134 & Log likelihood & & 7.252774 \\
Hannan-Quinn criter. & 1.912564 & F-statistic & & \\
Durbin-Watson stat & 0.495032 & Prob(F-statistic) & & 0.000037
\end{tabular}

Diperoleh persamaan regresi data panel sebagai berikut:

$\mathrm{HS}=2,3863+0,0257 \mathrm{ROA}+0,0008 \mathrm{CR}+0,0125 \mathrm{INFLASI}+0,0274 \mathrm{PDB}$

4.2. Hasil Uji Asumsi Klasik

4.2.2. Uji Normalitas

Dengan melihat nilai Jarque-Bera diperoleh hasil:

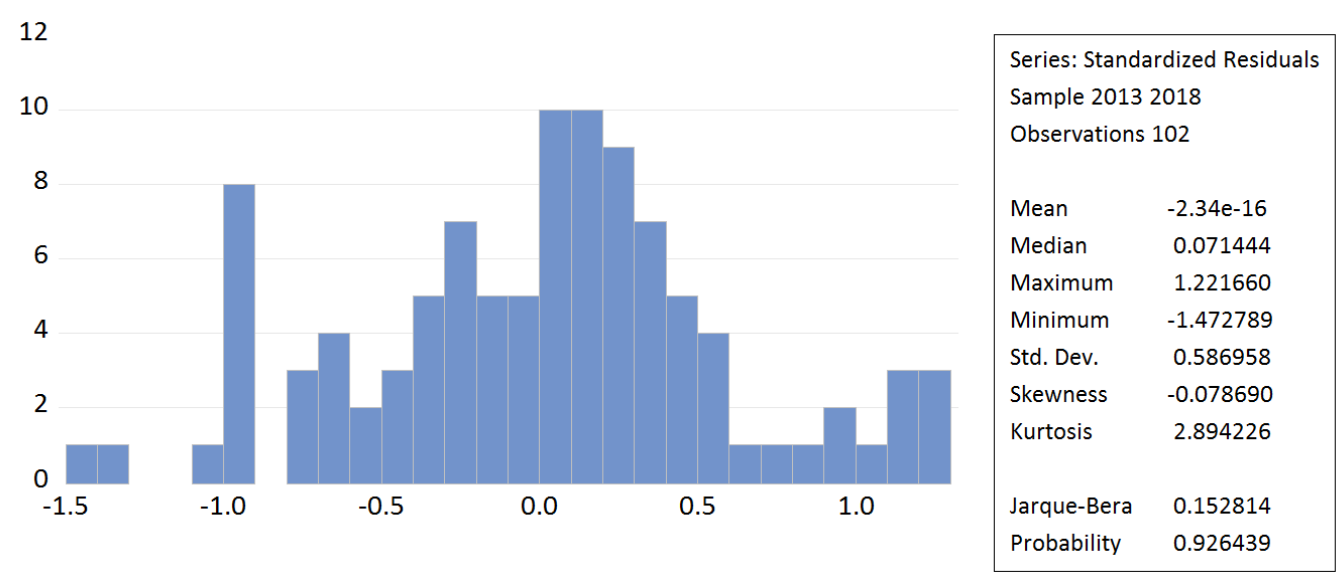

Gambar. 2 Hasil Uji Normalitas

Dapat diketahui bahwa nilai probabilitas Jarque-Bera adalah sebesar 0,926439 yakni lebih dari 0,05. Artinya, data yang dipakai terdistribusi normal.

4.2.3. Uji Multikolinearitas

Dengan menggunakan Pearson Correlation diperoleh hasil:

Tabel. 6 Hasil Uji Multikolinearitas

$\begin{array}{ccccc} & \text { ROA } & \text { CR } & \text { INFLASI } & \text { PDB } \\ \text { ROA } & 1.000000 & 0.007373 & 0.030498 & 0.094762 \\ \text { CR } & 0.007373 & 1.000000 & -0.046114 & 0.048616 \\ \text { INFLASI } & 0.030498 & -0.046114 & 1.000000 & 0.537894 \\ \text { PDB } & 0.094762 & 0.048616 & 0.537894 & 1.000000\end{array}$




\section{Kirana Arenggaraya, Tjetjep Djuwarsa}

Dapat dilihat bahwa nilai koefisien antar variabel tidak ada yang lebih dari 0,9. Dapat ditarik kesimpulan bahwa data yang dipakai tidak terjangkit multikolinearitas.

\subsubsection{Uji Heteroskedastisitas}

Dengan menggunakan uji Glejser diperoleh hasil:

Tabel .7 Hasil Uji Heteroskedastisitas

$\begin{array}{crrrr}\text { Variable } & \text { Coefficient } & \text { Std. Error } & \text { t-Statistic } & \text { Prob. } \\ & & & & \\ \text { C } & -0.023456 & 0.537157 & -0.043667 & 0.9653 \\ \text { ROA } & -0.000753 & 0.002347 & -0.321040 & 0.7490 \\ \text { CR } & 0.000210 & 0.000243 & 0.864370 & 0.3899 \\ \text { INFLASI } & 0.002606 & 0.009807 & 0.265775 & 0.7911 \\ \text { PDB } & 0.083292 & 0.110908 & 0.751002 & 0.4548\end{array}$

Dapat dilihat bahwa nilai probabilitasnya lebih dari 0,05. Dapat ditarik kesimpulan bahwa data yang dipakai tidak terjangkit heteroskedastisitas.

4.2.5. Uji Autokorelasi

Dengan melihat nilai Durbin-Watson diperoleh hasil:

\begin{tabular}{|c|c|c|c|c|}
\hline \multicolumn{5}{|c|}{ Tabel. 8 Hasil Uji Autokorelasi } \\
\hline Variable & Coefficient & Std. Error & t-Statistic & Prob. \\
\hline $\mathrm{C}$ & 1.673662 & 0.557057 & 3.004472 & 0.0035 \\
\hline ROA & 0.001096 & 0.002433 & 0.450451 & 0.6536 \\
\hline CR & -0.000255 & 0.000252 & -1.012923 & 0.3141 \\
\hline INFLASI & 0.002858 & 0.010170 & 0.281053 & 0.7794 \\
\hline PDB & 0.243912 & 0.115017 & 2.120672 & 0.0370 \\
\hline \multicolumn{5}{|c|}{ Effects Specification } \\
\hline \multicolumn{5}{|c|}{ Cross-section fixed (dummy variables) } \\
\hline Root MSE & 0.183884 & \multicolumn{2}{|c|}{ R-squared } & 0.923701 \\
\hline Mean dependent var & 2.888369 & \multicolumn{2}{|c|}{ Adjusted R-squared } & 0.904862 \\
\hline S.D. dependent var & 0.668999 & \multicolumn{2}{|c|}{ S.E. of regression } & 0.206349 \\
\hline Akaike info criterion & -0.137256 & \multicolumn{2}{|c|}{ Sum squared resid } & 3.448967 \\
\hline Schwarz criterion & 0.403179 & \multicolumn{2}{|c|}{ Log likelihood } & 28.00007 \\
\hline Hannan-Quinn criter. & 0.081584 & \multicolumn{2}{|l|}{ F-statistic } & 49.03087 \\
\hline Durbin-Watson stat & 2.049272 & \multicolumn{2}{|l|}{ Prob(F-statistic) } & 0.000000 \\
\hline
\end{tabular}

Dapat dilihat bahwa nilai Durbin-Watson sebesar 2,049272. Merujuk dari tabel Durbin-Watson, hasilnya dapat diperoleh melalui tabel berikut:

Tabel. 9 Hasil Uji dengan Durbin-Watson 


\begin{tabular}{|l|l|}
\hline Durbin-Watson & 2,049272 \\
\hline K (jumlah variabel) & 4 \\
\hline Jumlah Observasi & 102 sampel \\
\hline dL & 1,5969 \\
\hline dU & 1,7596 \\
\hline $4-d L$ & 2,4031 \\
\hline $4-d U$ & 2,2404 \\
\hline
\end{tabular}

Hasil di atas dapat dituliskan dengan 1,7596<2,049272<2,2404. Dapat ditarik kesimpulan bahwa data yang digunakan tidak terjangkit autokorelasi.

4.3. Hasil Uji Hipotesis

4.3.1. Uji t-statistik

Dengan melihat nilai signifikansi diperoleh hasil:

Tabel. 10 Hasil Uji t-statistik

\begin{tabular}{ccccc} 
Variable & Coefficient & Std. Error & t-Statistic & Prob. \\
\hline C & 2.386303 & 1.611446 & 1.480846 & 0.1419 \\
ROA & 0.025706 & 0.005214 & 4.930582 & 0.0000 \\
CR & 0.000880 & 0.000452 & 1.946281 & 0.0545 \\
INFLASI & 0.012541 & 0.029334 & 0.427522 & 0.6699 \\
PDB & 0.027418 & 0.330431 & 0.082976 & 0.9340
\end{tabular}

Pengujian Hipotesis Pertama $\left(\mathrm{H}_{1}\right)$

Dapat diketahui nilai probabilitas ROA sebesar 0,000 yakni lebih kecil dari taraf 0,05 dan berkoefisien positif. Artinya bahwa variabel independen ROA secara parsial berpengaruh positif dan signifikan terhadap harga saham, maka $\mathrm{H}_{1}$ diterima.

Pengujian Hipotesis Kedua $\left(\mathrm{H}_{2}\right)$

Dapat diketahui nilai probabilitas CR sebesar 0,0545 yakni lebih besar dari taraf 0,05 dan berkoefisien positif. Dapat ditarik kesimpulan bahwa variabel independen CR secara parsial berpengaruh positif dan tidak signifikan terhadap harga saham, maka $\mathrm{H}_{2}$ ditolak.

Pengujian Hipotesis Ketiga $\left(\mathrm{H}_{3}\right)$

Dapat diketahui nilai probabilitas inflasi sebesar 0,6699 yakni lebih besar dari taraf 0,05 dan berkoefisien positif. Hasilnya bahwa variabel independen inflasi secara parsial berpengaruh positif dan tidak signifikan terhadap harga saham, maka $\mathrm{H}_{3}$ ditolak.

Pengujian Hipotesis Keempat $\left(\mathrm{H}_{4}\right)$

Dapat diketahui nilai probabilitas PDB sebesar 0,9340 yakni lebih besar dari taraf 0,05 dan berkoefisien positif. Hasilnya bahwa variabel independen PDB secara parsial berpengaruh positif dan tidak signifikan terhadap harga saham, maka $\mathrm{H}_{4}$ ditolak.

4.3.2.Uji f-statistik

Dengan melihat nilai Prob(F-statistic) diperoleh hasil: 
Tabel. 11 Hasil Uji f-statistik

\begin{tabular}{cclll} 
Variable & Coefficient & Std. Error & t-Statistic & Prob. \\
\hline C & & & & \\
ROA & 2.386303 & 1.611446 & 1.480846 & 0.1419 \\
CR & 0.025706 & 0.005214 & 4.930582 & 0.0000 \\
INFLASI & 0.000880 & 0.000452 & 1.946281 & 0.0545 \\
PDB & 0.012541 & 0.029334 & 0.427522 & 0.6699 \\
& 0.027418 & 0.330431 & 0.082976 & 0.9340 \\
\hline & & & & \\
Root MSE & & & & \\
Mean dependent var & 2.8888369 & R-squared & \\
S.D. dependent var & 0.668999 & S.E. of regression & 0.230227 \\
Akaike info criterion & 1.860459 & Sum squared resid & 0.598938 \\
Schwarz criterion & 1.989134 & Log likelihood & -89.89646 \\
Hannan-Quinn criter. & 1.912564 & F-statistic & 7.252774 \\
Durbin-Watson stat & 0.495032 & Prob(F-statistic) & 0.000037
\end{tabular}

Dapat dilihat bahwa nilai Prob(F-statistic)adalah 0,000037 yakni kurang dari taraf 0,05. Sehingga ROA, CR, inflasi, dan PDB secara simultan berpengaruh positif signifikan terhadap harga saham, $\mathrm{H}_{5}$ diterima.

4.4. Pembahasan Hasil Penelitian

4.4.1. Pengaruh ROA Terhadap Harga Saham

Dari pengolahan data yang telah dilakukan, ROA berpengaruh positif signifikan terhadap harga saham karena nilai probabilitasnya 0,0000 yakni lebih kecil daripada taraf 0,05 . Hasil ini didukung oleh teori yang menyebutkan bahwa ROA yang meningkat berakibat pada peningkatan daya tarik investor untuk menanamkan modal pada perusahaan tersebut karena profitabilitas perusahaan meningkat, yang nanti akan berdampak pula pada harga saham. Hasil ini sama dengan penelitian Ananda (2018) yang menyebutkan bahwa ROA berpengaruh positif signifikan terhadap harga saham.

\subsubsection{Pengaruh CR Terhadap Harga Saham}

Dari pengolahan data yang telah dilakukan, CR berpengaruh positif dan tidak signifikan terhadap harga saham karena nilai probabilitasnya 0,0545 yakni lebih besar dari taraf 0,05. Artinya, investor tidak terlalu memperhatikan nilai CR sebagai keputusan untuk menanam modal. Hal ini bertentangan dengan penelitian Ananda (2018) yang menyebutkan bahwa CR berpengaruh terhadap harga saham.

\subsubsection{Pengaruh Inflasi Terhadap Harga Saham}

Dari pengolahan data yang telah dilakukan, inflasi berpengaruh positif dan tidak signifikan terhadap harga saham karena nilai probabilitasnya 0,6699 yakni lebih besar daripada 0,05. Hal ini disebabkan pada tahun 2013 dan 2014 inflasi meningkat namun menurun pada tahun 2015 sampai dengan 2018. Meskipun begitu, perekonomian masih terkendali dengan baik dan membuat investor masih ingin melakukan investasi. Hal ini menandakan bahwa bursa saham khususnya ISSI masih bisa menerima laju inflasi pada tahun tersebut. Hasil ini bertentangan dengan penelitian Artiani \& Sari (2019) yang menyebutkan bahwa inflasi berpengaruh signifikan terhadap harga saham.

\subsubsection{Pengaruh PDB Terhadap Harga Saham}

Dari pengolahan data yang telah dilakukan, PDB berpengaruh positif dan tidak signifikan terhadap harga saham karena nilai probabilitasnya 0,9340 yakni lebih besar dari taraf 0,05 . 
Artinya, PDB kurang mampu memberi dampak pada minat investor untuk menanamkan modal. Meningkatnya PDB menunjukkan adanya peningkatan produktifitas yang akan berakibat pada meningkatnya pendapatan negara, namun hal tersebut ternyata tidak menjadi pertimbangan investor. Merujuk Christie et al., (2015) bahwa ketika ada fluktuasi harga saham, investor tidak beranggapan saham tersebut memiliki potensi untuk memberi keuntungan di masa yang akan datang hingga akhirnya investor urung menanamkan modal yang tentu akan berakibat pada harga saham. Hasil ini bertentangan dengan penelitian yang dilakukan Sholihah (2018) yang menyebutkan bahwa PDB berpengaruh signifikan terhadap harga saham.

4.4.5. Pengaruh ROA, CR, inflasi, dan PDB terhadap Harga Saham

Dari pengolahan data yang telah dilakukan, secara simultan ROA, CR, inflasi, dan PDB berpengaruh positif signifikan terhadap harga saham karena nilai probabilitasnya 0,000037 yakni lebih kecil dari taraf 0,05. Hasil ini sama dengan penelitian Ananda (2018) yang menyebutkan bahwa ROA, CR, TATO, PER dan volume perdagangan berpengaruh signifikan terhadap harga saham secara simultan. Begitu pula dengan penelitian Sholihah (2018) yang menyebutkan bahwa nilai tukar, inflasi, PDB dan kinerja lingkungan berpengruh terhadap harga saham secara simultan.

\section{Penutup}

\subsection{Kesimpulan}

Dari hasil penelitian mengenai analisis pengaruh faktor internal dan faktor eksternal terhadap harga saham perusahaan sektor pertambangan yang terdaftar dalam Indeks Saham Syariah Indonesia (ISSI) periode 2013-2018, dapat diketahui kesimpulan:

1. Variabel Return on Asset (ROA) secara parsial berpengaruh positif dan signifikan terhadap harga saham. Artinya, ROA mempengaruhi tingkat harga saham perusahaan sektor pertambangan yang terdaftar di ISSI pada tahun 2013-2018 dan $\mathrm{H}_{1}$ diterima.

2. Variabel Current Ratio (CR) secara parsial berpengaruh positif dan tidak signifikan terhadap harga saham. Artinya, CR tidak berpengaruh secara signifikan terhadap harga saham perusahaan sektor pertambangan yang terdaftar di ISSI pada tahun 2013-2018 dan $\mathrm{H}_{2}$ ditolak.

3. Variabel inflasi secara parsial berpengaruh positif dan tidak signifikan terhadap harga saham. Artinya, inflasi tidak berpengaruh secara signifikan terhadap harga saham perusahaan sektor pertambangan yang terdaftar di ISSI pada tahun 2013-2018 dan $\mathrm{H}_{3}$ ditolak.

4. Variabel Produk Domestik Bruto (PDB) secara parsial berpengaruh positif dan tidak signifikan terhadap harga saham. Artinya, PDB tidak berpengaruh secara signifikan terhadap harga saham perusahaan sektor pertambangan yang terdaftar di ISSI tahun 2013-2018 dan $\mathrm{H}_{4}$ ditolak.

5. Variabel independen ROA, CR, Inflasi dan PDB secara simultan berpengaruh positif dan signifikan terhadap harga saham. Artinya, secara bersamaan ROA, CR, inflasi dan PDB mempengaruhi harga saham perusahaan sektor pertambangan yang terdaftar dalam ISSI tahun 2013-2018 dan $\mathrm{H}_{5}$ diterima.

\subsection{Saran}

Berdasarkan hasil penelitian serta kesimpulan yang diperoleh, saran yang dapat menjadi masukan bagi pihak-pihak yang berkepentingan adalah sebagai berikut:

1. Bagi investor, saat memprediksi harga saham juga turut memperhatikan faktor internal dan faktor eksternal lainnya yang mungkin berdampak pada harga saham. Selalu amati 
perekonomian yang sedang terjadi agar pengambilan keputusan investasi dilakukan secara tepat. Selain itu, memiliki manajer investasi dapat dijadikan opsi agar diarahkan dalam berinvestasi dengan benar.

2. Bagi perusahaan, harus senantiasa meningkatkan profitabilitas perusahaannya. Hal tersebut menjadi salah satu faktor pertimbangan utama bagi investor.

\section{Daftar Pustaka}

Ananda, S. T. (2018). Analisis Pengaruh Return on Asset (ROA), Current Ratio (CR), Total Asset Turnover (TATO), Price Earning Ratio (PER), dan Volume Perdagangan Terhadap Harga Saham Pada Sektor Pertambangan Batubara yang Terdaftar di Indeks Saham Syariah Indonesia (ISSI) Tahu. Director, 15(April), 2017-2019.

Artiani, L. E., \& Sari, C. U. P. (2019). Pengaruh variabel makro dan harga komoditas tambang terhadap harga saham sektor pertambangan di indeks saham syariah Indonesia (ISSI). Jurnal Ekonomika, X(02), 1-10.

Atmaja, L. (2008). Teori dan Praktek Manajemen Keuangan. In Yogyakarta: ANDI.

Boediono, D. R. (1999). Seri Sinopsis Pengantar Ilmu Ekonomi No. 1 Ekonomi Mikro. BPFE.

Christie, M. B., Khairunnisa, \& Dillak, V. J. (2015). Pengaruh Variabel Makroekonomi Di Pasar Saham : Bukti Dari Bursa Efek Indonesia (BEI) Periode 2006-2015. MODUS.

Hartono, J. (2010). Teori Portofolio dan Analisis Investasi (Edisi Sepuluh). In Yogyakarta: BPFE.

Hijriyani, N. Z., \& Setiawan, S. (2017). Analisis Profitabilitas Perbankan Syariah di Indonesia sebagai Dampak Dari Efisiensi Operasional. Jurnal Kajian Akuntansi, 1(2).

IDX. (2018). Indonesia Stock Exchange. Stock Summary.

Kasmir. (2014). Analisis Laporan Keuangan, Edisi Satu, Cetakan Ketujuh. In Raja Grafindo Persada.

Mai, M. U., \& Setiawan, S. (2020). Pengaruh Struktur Modal Terhadap Kinerja Perusahaan Pada Industri Manufaktur Kriteria Syariah Di Bursa Efek Indonesia. Jurnal Riset Akuntansi dan Keuangan, 8(1), 159-170.

Mankiw, N. G. (2010). Macroeconomics (7th Ed). In Worth Publishers.

Munawir. (2010). Analisa Laporan Keuangan Edisi 4. In Jakarta: Salemba Empat.

Nadya, G. R., Mai, M. U., \& Setiawan, S. (2020). Pengaruh Corporate Sosial Responsibility Terhadap Kinerja Perusahaan Pada Perusahaan Manufaktur Syariah. Ekonomi \& Bisnis, 19(1), 69-78.

Natsir, M. (2014). Ekonomi Moneter dan Kebanksentralan. Mitra Wacana Media.

Nurrachmi, I., \& Setiawan, S. (2020). Peran Koperasi Syariah Sebagai Pusat Kegiatan Muamalah Jamaah Masjid (Studi Kasus Koperasi Syariah Baitul Mu'min Komplek Pasir Jati, Desa Jati Endah Kecamatan Cilengkrang Kabupaten Bandung). Jurnal Ilmiab Mizani: Wacana Hukum, Ekonomi, dan Keagamaan, 7(1), 59-72.

OJK. (2018). Saham syariah. Otoritas Jasa Keuangan.

Pew Forum On Religion And Public Life. (2009). Mapping the Global Muslim Population: A Report on the Size and Distribution of the World's Muslim Population. Pew Research Center.

Rakasetya, G. (2013). Pengaruh Faktor Mikro Dan Faktor Makro Ekonomi Terhadap Harga Saham Perusahaan Mining And Mining Services Yang Terdaftar Di Bursa Efek Indonesia (Bei) Periode 2008-2011. Jumal Administrasi Bisnis $S 1$ Universitas Brawijaya. 
Samsul, M. (2006). Pasar modal dan manajemen portofolio. Jakarta: Erlangga.

Sartono. (2019). Sartono, R. Agus. 2001. Manajemen Keuangan Teori dan Aplikasi. Edisi 4. Yogyakarta: BPFE. Revolusi Industri 4.0: Desain Perkembangan Transaksi Dan Sistem Akuntansi Keuangan.

Setyowati, D. H. (2018). Analisis Kinerja Kenangan Bank Umum Syariah Sebagai Dampak Inefisiensi Operasional. 1-14.

Setyowati, D. H., \& Sartika, A. (2019). Faktor-Faktor yang Mempengarubi Pangsa Pasar Industri Keuangan Syariah Non-Bank. 169-186.

Sholihah, R. M. (2018). Pengarub Nilai Tukar, Inflasi, Pertumbuhan PDB dan Kinerja Lingkungan Terbadap Harga Saham Syariah Sektor Pertambangan yang Tergabung Dalam Indeks Sabam Syariah Indonesia (ISSI) Periode 2013-2016. Skripsi, tidak dipublikasikan

Sugiyono. (2014). Metode Penelitian Pendidikan pendekatan Kuantitatif, Kualitatif dan R\&D. Bandung: Alfabeta.

Suhartanto, D., Farhani, N. H., \& Muflih, M. (2018). Loyalty Intention towards Islamic Bank: The Role of Religiosity, Image, and Trust. International Journal of Economics \& Management, 12(1).

Sukirno, S. (2005). Makroekonomi Modern: Perkembangan Pemikiran Dari Klasik Hingga Keynesian Baru. In Jakarta, Rajawali Pers.

Tripuspitorini, F. A. \& Setiawan. (2020). Pengarub Faktor Makroekonomi Terhadap Pertumbuban Dana Pihak Ketiga Pada Bank Umum Syariah di Indonesia. 8(1), 121-132.

Wild, John, K.R. Subramanyam, dan R. F. H. (2005). Analisis Laporan Keuangan. Edisi Delapan, Buku Kesatu. Alih Bahasa: Yanivi dan Nurwahyu. In Jakarta: Salemba Empat.

Witjaksono, A. A. (2010). Analisis Pengaruh Tingkat Suku Bunga SBI, Harga Minyak Dunia, Harga Emas Dunia, Kurs Rupiah, Indeks Nikkei 225, dan Indeks Dow Jones terhadap IHSG. Tesis Universitas Diponegoro. 